Potravinarstvo Slovak Journal of Food Sciences

vol. 13, 2019, no. 1, p. 25-31

doi: https://doi.org/10.5219/824

Received: 19 October 2018. Accepted: 18 November 2018.

Available online: 31 January 2019 at www.potravinarstvo.com

(C) 2019 Potravinarstvo Slovak Journal of Food Sciences, License: CC BY 3.0

ISSN 1337-0960 (online)

\title{
ECOTOXICOLOGICAL STUDIES OF AKMOLA REGION LAKES
}

\author{
Lyailya Akbayeva, Erdaulet Tulegenov, Ainur Omarbayeva, Nazira Kobetaeva, \\ Zina Nurgalieva, Yerlan Nurkeyev, Patrícia Martišová, Vladimir Vietoris, Assylbek Zhanabayev
}

\begin{abstract}
The research object is water, bottom sediments in Akmola region lakes located in the intensive agriculture area. The territory of Akmola region is subjected to intensive human impacts, including the inevitable pollution with agricultural pesticides, which are ecotoxicants. The work has carried out hydrochemical studies in technogenic polluted lakes: general hydrochemical indicators, persistent organic pollutant content. The POPs in the samples were determined on the gas chromatograph Clarus 580 (PerkinElmer) with a mass spectrometer detector Clarus-SQ 8. According to the analysis results, the general hydrochemical pollution is classified as an average. The MPC excess indicators in the Akmola region lakes are observed for salt ammonium (up to $0.002 \mathrm{MPC}$ ), magnesium (up to $1.15 \mathrm{MPC}$ ), nitrites (up to $1.12 \mathrm{MPC}$ ), petroleum products (up to $1.98 \mathrm{MPC}$ ), iron (up to 2.0 MPC), SSAS (up to $3.8 \mathrm{MPC}$ ). High concentration indicators for the sulphate (3.5 MPC), copper (4.3 MPC), magnesium (1.125 MPC). Mainly the lakes are dominated by sulfates, ion chloride. But in general among 21 investigated POPs 8 substances are accumulated in bottom sediments of the investigated Zhalauly, Tastykol lakes, Unnamed Lake to the south of Akkol village, Itemgen lake, Zhalanash lake near Malinovka village (near Astana city), Kokay, Yesey, Bolshoe Chebachie.
\end{abstract}

Keywords: ecotoxicants; persistent organic pollutants; monitoring; accumulation; lake

\section{INTRODUCTION}

In Kazakhstan there is still no universal systematic monitoring of persistent organic pollutants (Kholubek et al., 2012). Upon that, a number of pilot projects of initial assistance to the Republic of Kazakhstan on obligations under the Stockholm Convention on Persistent Organic Pollutants has given reasoned conclusion that the problem is urgent in the republic (Kholubek et al., 2012; Zhanadilov et al., 2015.; Shabanova et al., 2010). This primarily relates to areas exposed to intense pollution by agricultural pesticides.

Ecological problems of Akmola region is largely determined by agro-industrial specialization of the region. The main branch of the region specialization is the production and processing of agricultural products (76\%), including grain production $-56.8 \%$. Akmola region has the highest percentage of rural population - $54.8 \%$ (Investment opportunities of the region, 2017; Sydykov et al., 2004; Seitkasymova, 2015).

The industry of this region is represented by the gold ore, uranium extraction, pharmaceutical and chemical industry, machine building and production of building materials (Sydykov et al., 2004; Press service of the Prime Minister of the Republic of Kazakhstan, 2018).
The area is rich in land resources. The total area of agricultural land is 13,791.7 thousand ha, areas of natural pastures are wide and occupy 6592.5 thousand hectares, the arable land is about 7,100 thousand ha. Almost all arable lands use some insecticides, fungicides - substances that are long-persistent in the environment, accumulated in the soil, in bottom sediments of stagnant water (Ljunggren et al., 2014; Jepson and Law, 2016).

In addition, the territory of the region under study still keep in some places some pesticides in abandoned warehouses without recycling, that were applied since the middle of last century. Names, respectively, contents of some pesticides are no longer possible to determine without analytical tests.

Thus, the territory of Akmola region is subjected to intensive human impacts, including the inevitable pollution with agricultural pesticides, which are ecotoxicants.

Detecting most POPs directly in water is not recommended (Kholubek et al., 2012; Ministry of Health of the USSR, 1987) because many of them are insoluble in water, and soluble POPs can be eliminated through bioaccumulation in living organism tissues. Thus, in our opinion, monitoring surface water for the POP content should begin with bottom sediments. In this case, 
hydrochemical indicators should be analyzed as the accompanying background or synergistic factor increasing violations in biocenosis and pathomorphology of aquatic organisms (Yemelyanova and Lobchenko, 2002.; WHO, 2011; Kukeyeva et al., 2015; Grancová-Bielková and Sokol, 2010; Akbayeva et al., 2014).

The research aim: Study the content of ecotoxicants in the Akmola region lakes.

\section{Scientific hypothesis}

In Kazakhstan, by virtue of years of the uncontrolled POPs use and production of industrial toxins, violations of their operation and storage rules, a unique dangerous xenobiotic profile could emerge, which practically has not been studied (Akbayeva et al., 2016).

In the Republic of Kazakhstan, an average of up to $0.57 \mathrm{~kg}$ of pesticides was applied per 1 ha of arable land (Shabanova et al., 2010). Considering that pesticides were used from the 50s, about 475 tons of pesticides were used on the territory of the Akmola region with an area of 14,621.9 hectares until 2008, including POPs pesticides. In this regard, pesticides from contaminated soil should ultimately accumulate at the bottom of water bodies. Thus, lakes are the ultimate storage of POPs.

The research results should be informative and methodological rationale for more extensive researches in this area.

\section{MATERIAL AND METHODOLOGY}

In 2016 some of the chemical components was studied in the water and bottom sediments of the Akmola region lakes: Zhalauly and Tastykol lakes, the unnamed lake to the south of the district center of Akkol village and unnamed lake $40 \mathrm{~km}$ south from Astrakhanka village, Itemgen lake at Buland village, Zhalanash lake at Malinovka village (near Astana city). These lakes are located on the territory of the agricultural pesticides intensive use or places of POP substances storage. Lakes of the Korgalzhyn lake system: Kokay, Yesey, Sultankeldy are located in the south of the Akmola region territory in the lower part of the Nura River valley, which runs a large farmland. There have also been studied lakes of Shchuchinsk - Borov resort zone Borovoye and Bolshoe Chebachie that are under intensive anthropogenic impact.

In the lakes, hydrochemical samples of water and bottom sediment were selected in the summer months of July - August 2016.

These analyzes have determined the Hydrochemical water pollution index (WPI) (Sibagatullina and Mazurkin, 2009).

\section{Determining POPs in bottom sediments}

It has been carried out in accordance with the methodological guidelines for determining $\mathrm{HCH}$ and DDT in silt sulfide medical muds with gas-liquid chromatography (Ministry of Health of the USSR, 1987). The samples were selected with a bottom sampler from $10-70 \mathrm{~cm}$ depth from the surface. Samples were taken at five points by the "envelope" principle. Selected from all the mud was thoroughly mixed, and an average sample was selected in a glass jar of $500 \mathrm{~mL}$. For further analysis, grounds were air dried.
The POPs in the samples were determined on the gas chromatograph Clarus 580 (PerkinElmer) with a mass spectrometer detector Clarus-SQ 8.

Chromatographic conditions: capillary column RestekRxi®-1 ms $0.25 \mathrm{~mm}$ x $30 \mathrm{~m}$ x $0.25 \mathrm{~mm}$, sample volume: $1.0 \mathrm{mcL}$, the carrier gas, the carrier gas velocity: $1 \mathrm{ml} \cdot \mathrm{min}^{-1}$, flow division of $1: 25$, $\mathrm{t}$ columns: $40{ }^{\circ} \mathrm{C}$, the rise of $2{ }^{\circ} \mathrm{C} . \mathrm{min}^{-1}$ to $280{ }^{\circ} \mathrm{C}$, $\mathrm{t}$ evaporator $-280{ }^{\circ} \mathrm{C}$, mass spectrometric detector: $\mathrm{t}-240{ }^{\circ} \mathrm{C}$, EI $+=70 \mathrm{eB}$, the scanning time -4 to 120 minutes, the ion scan mode $-39-500 \mathrm{~m} \cdot \mathrm{z}^{-1}$.

\section{Statisic analysis}

All data were expressed as mean. The percentage components content was automatically calculated based on the peak areas of total ion chromatograms. The components were identified by mass spectra and retention times, using a NIST library.

\section{RESULTS AND DISCUSSION}

Indicators of the MPC excess in the Akmola region lakes for salt ammonium (up to 0.002 MPC), magnesium (up to 1.15 MPC), nitrites (up to 1.12 MPC), petroleum products (up to $1.98 \mathrm{MPC}$ ), iron (up to 2.0 MPC ), SSAS (up to 3.8 MPC). High concentration indicators for the sulphate (3.5 MPC), copper (4.3 MPC), magnesium (1.125 MPC). Mainly the lakes are dominated by sulfates, ion chloride (Table 1).

Lakes the most salty and with a hard water are Zhalauly and Zhalanash lakes - the water hardness of $7.5 \mathrm{mg} . \mathrm{dm}^{-3}$ and $8.37 \mathrm{mg} . \mathrm{dm}^{-3}$, respectively.

According to the water pollution index (WPI) the first class (relatively clean) may only include Sultankeldy, Yesey, Kokay waters; the second class (slightly dirty) - Zhalauly, Itemgen, Unnamed Lake (Akkol village) Zhalanash, Borovoe, Bolshoe Chebachie; the third class (polluted) - Tastykol, Unnamed Lake (Astrakhanka village) (Sibagatullina and Mazurkin, 2009).

Water is not recommended as a key matrix for lipophilic and non-Arctic initial twelve POPs, so the analysis of surface water is not recommended: for aldrin, chlordane, DDT, dieldrin, endrin, HCB, heptachlor, mirex, PCB, PCDP/PCDF, toxaphene. Water-soluble POPs: chlordecone, $\alpha-\mathrm{HCH}, \quad \beta-\mathrm{HCH}, \quad \gamma-\mathrm{HCH}, \quad$ PFOS (perfluorooctanesulfonate). Besides, the POP concentration in water may vary seasonally due to the seasonal activity of phytoplankton and certain organic substances, and other impacting factors, such as rainfall, flow volume, etc. Based on this, we have not detected POPs in the lake waters, and immediately began to define in the bottom sediments, where they can sediment as lipophilic compounds on the adsorbent composed of dead biota, benthic microorganisms.

Almost in all the studied lakes (Table 2), certain POPs have been found, except for the Unnamed Lake (at Astrakhanka village), Borovoye and Sultankeldy. Among the pesticides investigated by us, no sample has such compounds detected as: alpha-hexachlorocyclohexane, beta-hexachlorocyclohexane, chlordecone, hexabromobiphenyl, hexabromodiphenyl ether, lindane, hexachloran, mirex, pentachlorobenzene (in quintozene), perfluorooctane sulfonate and its salts, endosulfan and 
Table 1 Contents of the chemical components in the Akmola region lakes.

Akmola region lakes

\begin{tabular}{|c|c|c|c|c|c|c|c|c|c|c|c|c|}
\hline \multirow[b]{2}{*}{ Component name } & \multirow[b]{2}{*}{ MPC } & \multicolumn{11}{|c|}{ Akmola region lakes } \\
\hline & & 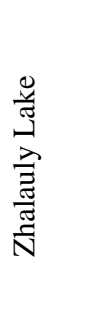 & 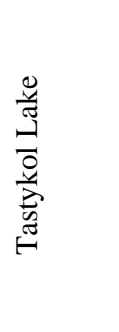 & 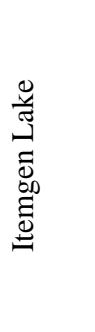 & 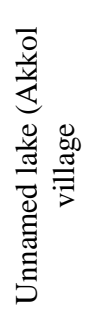 & 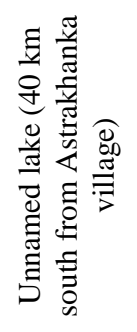 & 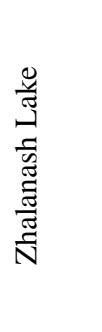 & 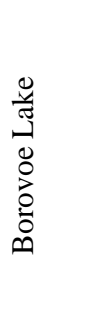 & 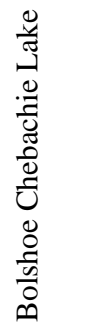 & 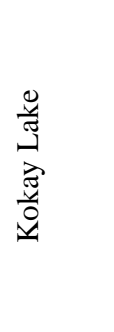 & 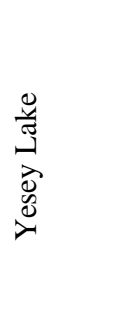 & 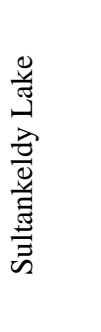 \\
\hline 1 & 2 & 3 & 4 & 5 & 6 & 7 & 8 & 9 & 10 & 11 & 12 & 13 \\
\hline Temperature, ${ }^{\circ} \mathrm{C}$ & & 14 & 18 & 18.8 & 23 & 19 & 18.9 & 22 & 20 & 16 & 22 & 24 \\
\hline $\mathrm{pH}$ value & & 8.25 & 6.7 & 8.2 & 6.6 & 7.6 & 8.1 & 7.8 & 7.9 & 7.6 & 7.7 & 7.0 \\
\hline BOD $5 \mathrm{mg} \cdot \mathrm{dm}^{-3}$ & 3 & 1.28 & 3.15 & 1.48 & 2.2 & 3.5 & 1.89 & 1.63 & 2.15 & 2.35 & 1.78 & 2.6 \\
\hline Calcium, mg.dm ${ }^{-3}$ & 180 & 76.6 & 10.23 & 84.2 & 21.63 & 63 & 90.8 & 68.5 & 78.3 & 65.3 & 55.2 & 45 \\
\hline Hardness, mEq. $\mathrm{dm}^{-3}$ & 10.0 & 7.5 & 1.7 & 7.1 & 1.49 & 5.19 & 8.37 & 3.7 & 4.37 & 3.7 & 3.4 & 2.65 \\
\hline Nitrite nitrogen, mg.dm ${ }^{-3}$ & 0.02 & 0.002 & 0.0012 & 0.009 & 0.001 & 0.002 & 0.001 & 0.002 & 0.013 & 0.004 & 0.003 & 0.001 \\
\hline Nitrite nitrogen, mg.dm ${ }^{-3}$ & 9.1 & 4.47 & 8.3 & 0.67 & 4.36 & 9.06 & 0.54 & 2.4 & 3.8 & 4.31 & 8.0 & 3.16 \\
\hline Sulfate ions, $\mathrm{mg} \cdot \mathrm{dm}^{-3}$ & 100 & 212 & 46.52 & 249 & 59.18 & 126.31 & 305 & 65.9 & 78.8 & 225 & 125 & 47.3 \\
\hline Chloride ions, $\mathrm{mg} \cdot \mathrm{dm}^{-3}$ & 300 & 277 & 222 & 268 & 196 & 276 & 291 & 150 & 79 & 147 & 198 & 146 \\
\hline Salt ammonium, mg.dm ${ }^{-3}$ & 0.5 & 0.98 & 0.42 & 0.02 & $0 / 07$ & 0.61 & 0.06 & 0.33 & 0.47 & 0.014 & 0.24 & 0.003 \\
\hline Phosphates, mg.dm ${ }^{-3}$ & 3.5 & 0.26 & 1.34 & 0.035 & 0.078 & 2.83 & 0.05 & 1.02 & 0.76 & 0.47 & 0.35 & 1.34 \\
\hline Total ferrum, mg.dm ${ }^{-3}$ & 0.1 & 0.065 & 0.03 & 0.072 & 0.04 & 0.16 & 0.049 & 0.08 & 0.1 & 0.03 & 0.02 & 0.02 \\
\hline SSAS, mg.dm ${ }^{-3}$ & 0.1 & 0.02 & 0.87 & 0.05 & 0.008 & 1.0 & 0.03 & 0.21 & 0.15 & 0 & 0 & 0.005 \\
\hline Magnesium, mg.dm ${ }^{-3}$ & 40 & 45.5 & 14.63 & 35.3 & 5.07 & 25 & 48.6 & 3.92 & 5.77 & 5.41 & 8.12 & 5.47 \\
\hline Copper, mg.dm ${ }^{-3}$ & 0.001 & 0.001 & 0.32 & 0.003 & 0.002 & 0.005 & 0.004 & 0.002 & 0.02 & 0 & 0.0002 & 0.0001 \\
\hline Petroleum products, mg.dm ${ }^{-3}$ & 0.05 & 0.033 & 0.003 & 0.120 & 0.054 & 0.06 & 0.134 & 0.05 & 0.046 & 0.0007 & 0.0007 & 0.006 \\
\hline WPI & - & 1.32 & 3.8 & 1.25 & 1.55 & 4.08 & 3.1 & 1.14 & 1.75 & 0.6 & 0.71 & 0.38 \\
\hline
\end{tabular}

isomers, tiodan, paraquat. Thus, among 21 tested substances, 12 substances are not accumulated in the bottom sediments of lakes studied.

Lake, where studied chlorinated pesticides are found, are located in areas of the most intensive agriculture, in particular, Zhalauly lake - where 5 pesticides are found (endrin, heptachlor, hexachlorobenzene, DDT, polychlorinated biphenyl), in 3 lakes 3 pesticides are found: Tastykol (aldrin, hexachlorobenzene, DDT), Itemgen (heptachlor, DDT, polychlorinated biphenyl) and Zhalanash (dieldrin, hexachlorobenzene, DDT). One pesticide - (hexa hexachlorobenzene), Bolshoe Chebachie
(Aldrin) and Yesey (Aldrin). 2 pesticides were found in Kokay lake (chlordane, hexachlorobenzene).

The quantitative pesticides distribution in lakes is shown in Table 3: aldrin has been found in 3 samples of Tastykol lake $\left(0.06 \times 10^{-6} \mathrm{mg} \cdot \mathrm{kg}^{-1}\right)$, Yesey $\left(0.3 \times 10^{-6} \mathrm{mg} \cdot \mathrm{kg}^{-1}\right)$, Bolshoe Chebachie $\left(1.8 \times 10^{-6} \mathrm{mg} \cdot \mathrm{kg}^{-1}\right)$, chlordane - in 1 Kokay lake $\left(1.3 \times 10^{-6} \mathrm{mg} \cdot \mathrm{kg}^{-1}\right)$, dieldrin in 1 Zhalanash lake $\left(0.04 \times 10^{-6} \mathrm{mg} \cdot \mathrm{kg}^{-1}\right)$, endrin - in 1 Zhalauly lake $\left(0.6 \times 10^{-6} \mathrm{mg} \cdot \mathrm{kg}^{-1}\right)$, heptachlor - in 2 Zhalauly lakes $\left(0.22 \times 10^{-6} \mathrm{mg} \cdot \mathrm{kg}^{-1}\right)$ and Itemgen $\left(0.04 \times 10^{-6} \mathrm{mg} \cdot \mathrm{kg}^{-1}\right)$, hexachlorobenzene was found in 5 Zhalauly lakes

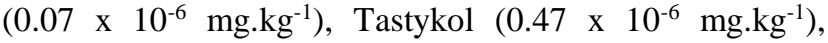


Table 2a POPs content in the bottom sediments of the Akmola region lakes.

\begin{tabular}{|c|c|c|c|c|c|c|c|c|c|c|}
\hline 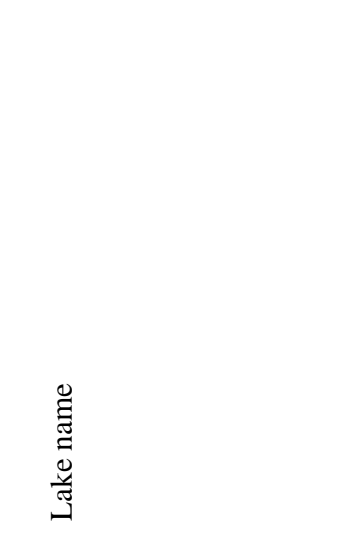 & 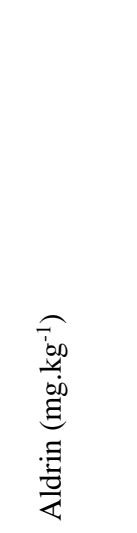 & 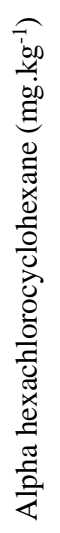 & 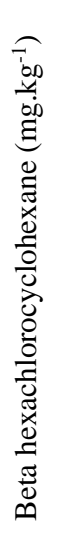 & 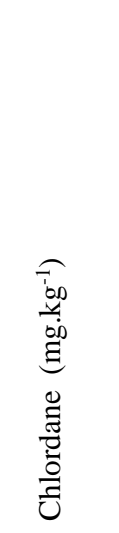 & 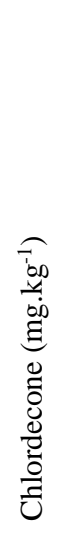 & 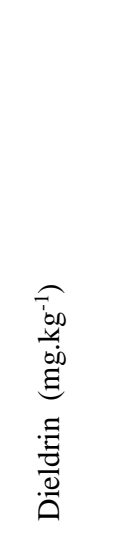 & 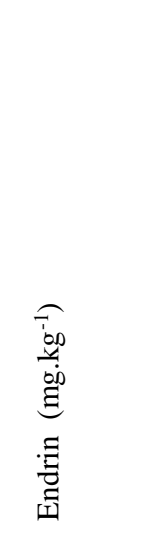 & 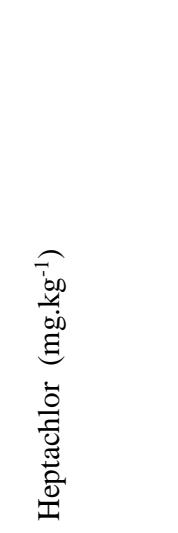 & 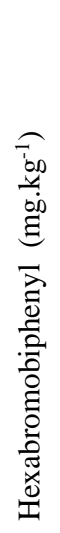 & 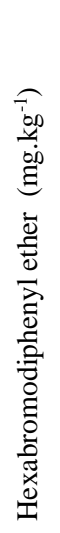 \\
\hline Zhalauly & - & - & - & - & - & - & $0.6 \cdot 10^{-6}$ & $0.22 \cdot 10^{-6}$ & - & - \\
\hline Tastykol & $0.06 \cdot 10^{-6}$ & - & - & - & - & - & - & - & - & - \\
\hline Itemgen & - & - & - & - & - & - & - & $0.04 \cdot 10^{-6}$ & - & - \\
\hline $\begin{array}{l}\text { Unnamed Lake in Akkol } \\
\text { village }\end{array}$ & - & - & - & - & - & - & - & - & - & - \\
\hline $\begin{array}{l}\text { Unnamed Lake in } \\
\text { Astrakhanka village }\end{array}$ & - & - & - & - & - & - & - & - & - & - \\
\hline Zhalanash & - & - & - & - & - & $0.04 \cdot 10^{-6}$ & - & - & - & - \\
\hline Borovoe & - & - & - & - & - & - & - & - & - & - \\
\hline Bolshoe Chebachie & $1.8 \cdot 10^{-6}$ & - & - & - & - & - & - & - & - & - \\
\hline Kokay & - & - & - & $1.3 \cdot 10^{-6}$ & - & - & - & - & - & - \\
\hline Yesey & $0.3 \cdot 10^{-6}$ & - & - & - & - & - & - & - & - & - \\
\hline Sultankeldy & - & - & - & - & - & - & - & - & - & - \\
\hline $\begin{array}{l}\text { Total amount of POPs } \\
\text { accumulated in the bottom } \\
\text { sediments of lakes }\end{array}$ & $2.16 \cdot 10^{-6}$ & & & $1.3 \cdot 10^{-6}$ & & $0.04 \cdot 10^{-6}$ & $0.6 \cdot 10^{-6}$ & $0.26 \cdot 10^{-6}$ & & \\
\hline
\end{tabular}

unnamed lake in Akkol village (0.066 x 10 $\left.10^{-6} \mathrm{mg} . \mathrm{kg}^{-1}\right)$, Zhalanash $\left(0.5 \times 10^{-6} \mathrm{mg} . \mathrm{kg}^{-1}\right)$, Kokay $\left(0.24 \times 10^{-6} \mathrm{mg} \cdot \mathrm{kg}^{-1}\right)$, DDT - in 4 Zhalauly lakes $\left(2.3 \times 10^{-6} \mathrm{mg} \cdot \mathrm{kg}^{-1}\right)$, Tastykol (1.57 x $\left.10^{-6} \mathrm{mg} \cdot \mathrm{kg}^{-1}\right)$, Itemgen (3.05 x $\left.10^{-6} \mathrm{mg} \cdot \mathrm{kg}^{-1}\right)$, Zhalanash $\left(2.34 \times 10^{-6} \mathrm{mg} \cdot \mathrm{kg}^{-1}\right)$, polychlorinated biphenyl - in 2 Zhalauly lakes $\left(0.31 \times 10^{-6} \mathrm{mg} \cdot \mathrm{kg}^{-1}\right)$, Itemgen $\left(1.87 \times 10^{-6} \mathrm{mg} . \mathrm{kg}^{-1}\right)$.

For all studied Akmola region lakes, the POPs content was summed and their specific content identified in the bottom sediments in the region. It is possible to draw up the next POPs decreasing row: 54\% (DDT) $>12.71 \%$ (polychlorinated biphenyl) $>12.59 \%$ (aldrin) $>7.85 \%$ (hexachlorobenzene) $>7.58 \%$ (chlordane) $>3.49 \%$ (endrin) $>1.51 \%$ (heptachlor) $>0.23 \%$ (dieldrin).
The proposed POPs row in the Akmola region may be represented as a diagram (Fig.1).

Thus, the studied waters cannot be classified as toxic as the POPs content in the bottom sediments is of background character, even without exceeding the maximum allowable concentrations of these substances in the water. However, the presence of these substances in the water may indicate the threat growing as environmentally long persistent toxicants will continue to be accumulated by different migration routes, as they are in the water (Gopal et al., 2016). As a result, this can be a serious obstacle to the production of organic products (Kádeková et al., 2017). 
Table $2 \mathbf{b}$ POPs content in the bottom sediments of the Akmola region lakes.

\begin{tabular}{|c|c|c|c|c|c|c|c|c|c|c|}
\hline 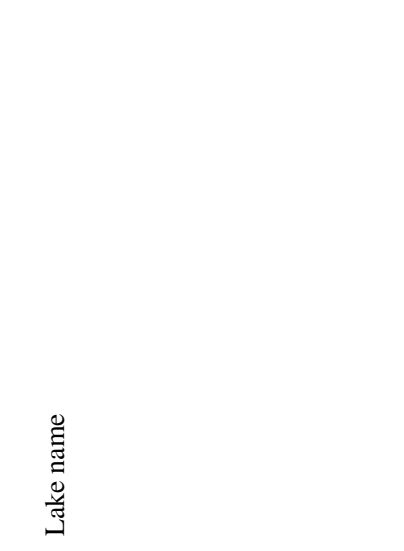 & 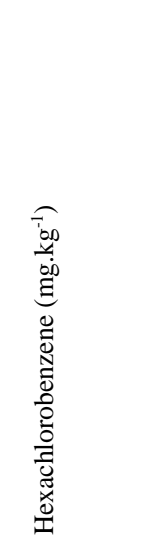 & 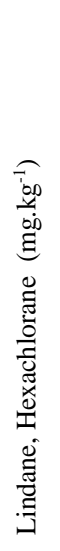 & 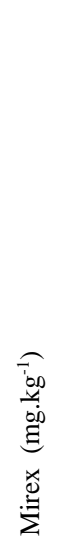 & 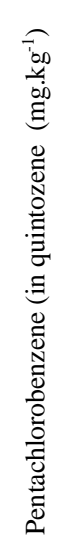 & 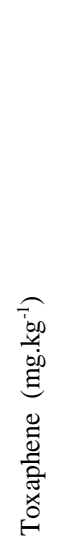 & 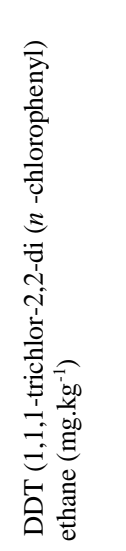 & 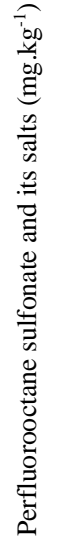 & 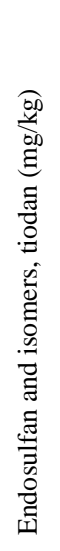 & 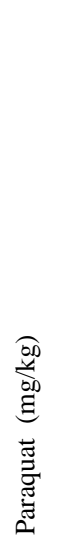 & 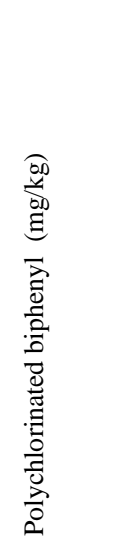 \\
\hline Zhalauly & $0.07 \cdot 10^{-6}$ & - & - & - & - & $2.3 \cdot 10^{-6}$ & - & - & - & $0.31 \cdot 10^{-6}$ \\
\hline Tastykol & $0.47 \cdot 10^{-6}$ & - & - & - & - & $1.57 \cdot 10^{-6}$ & - & - & - & - \\
\hline Itemgen & - & - & - & - & - & $3.05 \cdot 10^{-6}$ & - & - & - & $1.87 \cdot 10^{-6}$ \\
\hline Unnamed Lake in Akkol village & $0.066 \cdot 10^{-6}$ & - & - & - & - & - & - & - & - & - \\
\hline $\begin{array}{l}\text { Unnamed Lake in Astrakhanka } \\
\text { village }\end{array}$ & - & - & - & - & - & - & - & - & - & - \\
\hline Zhalanash & $0.5 \cdot 10^{-6}$ & - & - & - & - & $2.34 \cdot 10^{-6}$ & - & - & - & - \\
\hline Borovoe & - & - & - & - & - & - & - & - & - & - \\
\hline Bolshoe Chebachie & - & - & - & - & - & - & - & - & - & - \\
\hline Kokay & $0.24 \cdot 10^{-6}$ & - & - & - & - & - & - & - & - & - \\
\hline Yesey & - & - & - & - & - & - & - & - & - & - \\
\hline Sultankeldy & - & - & - & - & - & - & - & - & - & - \\
\hline $\begin{array}{l}\text { Total amount of POPs accumulated } \\
\text { in the bottom sediments of lakes }\end{array}$ & $1.346 \cdot 10^{-6}$ & & & & & $9.26 \cdot 10^{-6}$ & & & & $2.18 \cdot 10^{-6}$ \\
\hline
\end{tabular}

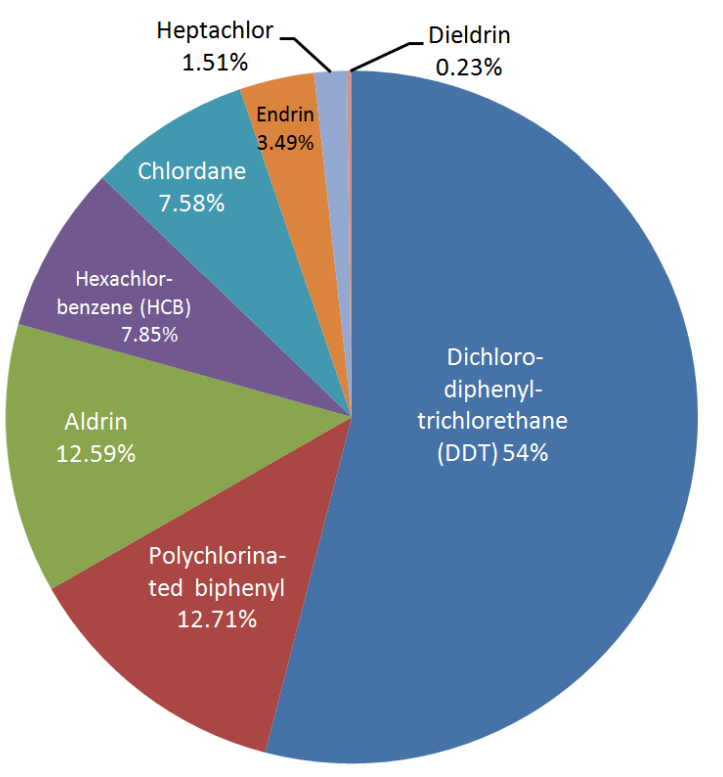

Figure 1 Generalized POPs share in bottom sediments of the Akmola region. 


\section{CONCLUSION}

The obtained results of the work performed for 2016 allow for the following conclusions:

1. The MPC excess indicators in the Akmola region lakes are observed for salt ammonium (up to 0.002 MPC), magnesium (up to $1.15 \mathrm{MPC}$ ), nitrites (up to $1.12 \mathrm{MPC}$ ), petroleum products (up to $1.98 \mathrm{MPC}$ ), iron (up to 2.0 MPC), SSAS (up to $3.8 \mathrm{MPC}$ ). High concentration indicators for the sulphate (3.5 MPC), copper (4.3 MPC), magnesium (1.125 MPC). Mainly the lakes are dominated by sulfates, ion chloride. Lakes the most salty and with a hard water are Zhalauly and Zhalanash lakes - the water hardness of $7.5 \mathrm{mg} \cdot \mathrm{dm}^{-3}$ and $8.37 \mathrm{mg} \cdot \mathrm{dm}^{-3}$, respectively. For the studied water pollution index, the I class (relatively clean) can include Sultankeldy, Esey, Kokay waters; the II class (slightly dirty) - Zhalauly, Borovoye, Bolshoe Chebachie.

2. Thus, accordance with sanitary requirements, the studied waters cannot be classified as toxic as the POPs content in the bottom sediments is of background character, even without exceeding the maximum allowable concentrations of these substances in the water. However, the presence of these substances in the water may indicate the threat growing as environmentally long persistent toxicants will continue to be accumulated by different migration routes, as they are in the water.

3. But in general among 21 investigated POPs 8 substances are accumulated in bottom sediments of the investigated Zhalauly, Tastykol lakes, Unnamed Lake to the south of Akkol village, Itemgen lake, Zhalanash lake near Malinovka village (near Astana city), Kokay, Yesey, Bolshoe Chebachie.

\section{REFERENCES}

Akbayeva, L. K. H., Zhamangara, A. K., Kobetaeva, N. K., Kumiskhanova, B. K., Nurmashev, A. B. 2016. Hydrochemical analysis of a number of the Akmola region lakes // Science and education: experience, problems and prospects of development: Part II. Science: experience, problems, prospects: Materials of XIV International Scientific-Practical Conference. (19-21 April 2016)/ Krasnoyarsk. State Agrarian. Univ. - Krasnoyarsk, p. 36-39. Available at: https://elibrary.ru/item.asp?id=26439013

Akbayeva, L., Muratov, R., Zhamangara, A., Beisenova, R., Zhantokov, B. 2014. Seasonal Dynamics of Phytoplankton and Bacterial Plankton Characteristics in Esil River. Biosciences Biotechnology Research Asia, vol. 11, no. 3. p. 1087-1093. https://doi.org/10.13005/bbra/1493

Gopal K., Surjeet S., Suman G., Kumar, C. P., Ghosh, N. C. 2016. Water Quality Assessment in Terms of Water Quality Index (WQI) Using GIS in Ballia District, Uttar Pradesh, India. Journal of Environmental \& Analytical Toxicology, vol. 6, no. 3, p. 1-6. https://doi.org/10.4172/21610525.1000366

Grancová-Bielková, Z., Sokol, J. 2010. Estimation of the burden of pesticide residues in slovak population. Potravinarstvo, vol. 4, no. 3. p. 6-9. doi: https://doi.org/10.5219/69

Investment opportunities of the region. 2017. Official Internet resource of Akmola region [online] s.a. [cit.2018-0815]. Available at: http://aqmola.gov.kz/page/read/Investicionnye_vozmozhnosti _regiona.html?lang=ru
Jepson, P. D., Law, R. J. 2016. Persistent pollutants, persistent threats. Science, vol. 352, no. 6292, p. 1388-1389. https://doi.org/10.1126/science.aaf9075

Kádeková, Z., Récky, R., Nagyová, L., Košičiarová, I., Holienčinová, M. 2017. Consumers' purchasing preferences towards organic food in Slovakia. Potravinarstvo Slovak Journal of Food Sciences, vol. 11, no 1, p. 731-738. https://doi.org/10.5219/846

Kholubek, I., Klanova, Y. A., Kochan, A. 2012. The structure of the proposed network for monitoring persistent organic pollutants (POPs) in Kazakhstan. Services for developing and implementing a training program on the PCB analysis and monitoring procedure. Part 2. Brno, Scientific cent RECETOX : Masaryk University, 27 p. Available at: https://docplayer.ru/42452162-Struktura-predlagaemoy-setipo-monitoringu-stoykih-organicheskih-zagryazniteley-soz-vkazahstane.html

Kukeyeva, F. T., Delovarova, L. F., Ormysheva, T. A., Shakirov, K. N. 2015. Sustainable Development and Water Management Issues: transboundary Rivers Management Gaps between Kazakhstan and China (Case of Ili and Irtysh). Oxidation Communications, vol. 38, no. 3, p. 1480-1490. ISSN 0209-4541.

Ljunggren, S. A., Helmfrid, I., Salihovic, S., van Bavel, B., Wingren, G., Lindahl, M., Karlsson, H. 2014. Persistent organic pollutants distribution in lipoprotein fractions in relation to cardiovascular disease and cancer. Environment $\begin{array}{lllll}\text { International, vol. } & 65, & \text { p. } & 93-99 .\end{array}$ https://doi.org/10.1016/j.envint.2013.12.017

Ministry of Health of the USSR. 1987. Methodical instructions for determining $\mathrm{HCCH}$ and DDT in silt sulfide medical mud by gas-liquid chromatography (approved by the Ministry of Health of the USSR 08.06.1987. N4343-87) Available at: http://lawru.info/dok/1987/06/08/n1180972.html

Press service of the Prime Minister of the Republic of Kazakhstan. 2018. Akmola region akimat website. Available at: https://primeminister.kz/page/article-83

Seitkasymova G. Z. 2015. Ecological and hygienic assessment of surface waters of populated areas of the Akmola region. Occupational health and medical ecology, vol. 4 , no. 49 , p. $78-82$.

Shabanova, L. V., Ishankulov, M. S., Undasynova, G. D., Dzhusupov, A. E., Sergazina, Z. K. 2010. Information and Analytical Center of Environmental Protection. Report on the Program 001 "Ensuring the authorized body work in the field of environment" on "Preparation of the first national report on persistent organic pollutants to the secretariat of the Stockholm Convention on POPs". Available at: http://referatdb.ru/pravo/114349/index.html

Sibagatullina, A. M., Mazurkin, P. M. 2009. Measurement of pollution of river water (on the example of the small river Malaya Kokshaga). Moscow, Russian Federation : Academy of Natural History, 71 p. ISBN: 978-5-91327-062-7.

Sydykov, Z., Baybatsha, A., Komekov, B., Serikbayev, K., Smagulov,O., Gabitov, T., Khalikov, H., Borbasov, S. 2004. Kazakhstan. National Encyclopedia Akmola region. $1^{\text {st }}$ ed. ALMATY, Kazakhstan : The Kazakh Encyclopedia, 561 p. ISBN 9965-9389-9-7.

WHO. 2011. Guidelines for Drinking-water Quality. GENEVA, Switzerland : WHO Press, 595 p. ISBN 924 1546964.

Yemelyanova, V. P., Lobchenko, E. E. 2002. The method of integrated assessment of the degree of contamination of surface water by hydrochemical indicators. Rostov-on-Don: Federal Service for Hydrometeorology and Environmental 
Monitoring (Roshydromet). Available at: http://files.stroyinf.ru/Index2/1/4293831/4293831806.html

Zhanadilov, A. Y., Ibragimova, L. A., Zhanadilova, G. K. 2015. Ways to solve the problem of resistant organic pollutants in Kazakhstan. International Journal of Experimental Education, no. 11-14, p. 603-605. Available at: http://expeducation.ru/ru/article/view?id=8659

\section{Acknowledgments:}

This work was supported by grant "Ecotoxicological studies of hydrobiocenoses of fishery reservoirs of the Esil river basin within the Akmola region", 2015-2017. funded by the Committee of Science MES RK.State registration number 0115 PK01390.

\section{Contact address:}

*Lyailya Akbayeva, Eurasian National University L. N. Gumilyov, Faculty of Natural Sciences, Department of Management and Engineering in the field of environmental protection, Satpayev Str., 2, 010008 Astana city, Kazakhstan, Tel.: +7(7172)709500(int33340), Email: akbaeva659@mail.ru

Erdaulet Tulegenov, Eurasian National University L. N. Gumilyov, Faculty of Natural Sciences, Department of Management and Engineering in the field of environmental protection, Satpayev Str., 2, 010008 Astana city, Kazakhstan, Tel.: +7(7172)709500(int33340), Email: er-daulet_kz@mail.ru

Ainur Omarbayeva, Eurasian National University L. N. Gumilyov, Faculty of Natural Sciences, Department of Management and Engineering in the field of environmental protection, Satpayev Str., 2, 010008 Astana city, Kazakhstan, Tel.: +7(7172)709500(int33114), Email: aynur.omarbaeva@mail.ru
Nazira Kobetaeva, Eurasian National University L. N. Gumilyov, Faculty of Natural Sciences, Department of Management and Engineering in the field of environmental protection, Satpayev Str., 2, 010008 Astana city, Kazakhstan, Tel.: +7(7172)709500(int33340), Email: kobetaeva.nazira@mail.ru

Zina Nurgalieva, Eurasian National L. N. Gumilyov, Faculty of Natural Sciences, Department of Management and Engineering in the field of environmental protection, Satpayev Str., 2, 010008 Astana city, Kazakhstan, Tel.: +7(7172)709500(int33340), E-mail: zinanurgalieva@mail.ru

Yerlan Nurkeyev, Kazakh National Pedagogical University, Abai. Institute of Natural History and Geography, Department of Ecology and Tourism. Kazybek Bi St. 30, Almaty city, Kazakhstan, Tel.: +7(7272)914766, E-mail: nurkeev.e@mail.ru

Patricia Martišová, Slovak University of Agriculture in Nitra, Faculty of Biotechnology and Food Sciences, Department of Storing and Processing of Plant Products, Tr. A. Hlinku 2, 94976 Nitra, Slovakia, Tel.: +421376414608, E-mail: xmartisovap@uniag.sk

Vladimir Vietoris, Slovak University of Agriculture in Nitra, Faculty of Biotechnology and Food Sciences, Department of Storing and Processing of Plant Products, Tr. A. Hlinku 2, 94976 Nitra, Slovakia, Tel.: +421376414793, E-mail: vietoris@ uniag.sk

Assylbek Zhanabayev, Saken Seifullin Kazakh Agro Technical University, Faculty of Veterinary and Livestock Technology, Department of Veterinary Medicine Zhenis avenue, 62, 10011 Astana city, Kazakhstan, Tel.: +7(7172)317547, E-mail: zhanabaev.asylbek@ mail.ru

Corresponding author: * 